\title{
選炭廃水処理に関する研 究“
}

\author{
一粒子の沈降挙動について——
}

\section{関口逸 馬 ${ }^{1}$ 植田芳 信 2 \\ 山口義 明 $^{3}$}

\section{1. 緒言}

選炭廃水中の固形物の沈降挙動は混入鈗物の多種多㥞 性, 広範囲の比重構成と粒度構成, $\mathrm{pH}$, 溶出イオンの種類 と量, 凝集剤などの影響を受けるから, 非常に複雑であ る。したがつて選炭廃水の沈降挙動を従来の考えにあて は方て解釈したり，その処理装置を計画したりすると実 際の挙動と適合しないことがある。

懸濁液中の固体粒子の沈降特性に関する今までの研究 はメスシリンダによる回分沈降曲線を求为，それを解析 したものが多い。それによれば沈降の初期では等速沈降 を示し, その後は沈降速度の減少する圧縮沈降となる。 そしてこのような沈降曲線の解析に利用される関係式と

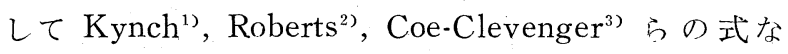
ど出〜゙がある。

しかしこれらの考えはいずれも比較的粒度の揃つた均 質な㲘濁液を対象としている。また沈降速度を界面の移 動から求め, 界面沈降曲線から考察をして打り, 沈積層 内の粒子の挙動から論じたものではない。すなわちより 精確に沈降を考える場合には沈積層内の濃度測定が必要 と考元られる。しかしこの観点から行なわれた実例は少 ない(8)9。。これは粒子の沈降を乱さず連続的に測定でき ることが必要で, 従来の方法では経時的に高さ方向の濃 度変化を測定することは困難もしくは不可能であつた。 $\gamma$ 線密度計はこれを解決する適切な装置であり, また選 炭廃水の上うな複雑で濃度範囲の広い懸濁液に対して,

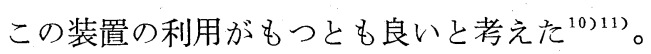

本報告は 2,3 の試料を使つた実験で, 測定精度ならび に種々の条件下に扝ける沈降濃度を測定した。この結 果, 粒子の沈降挙動に関して 2,3 の知見が得られたので ここに報告する ${ }^{12) 13 \text { 。 }}$

\section{2. $\gamma$ 線沈降濃度測定装置 ${ }^{11}$}

第 1 図に装置の略図を示した。装置は大倉電気製 $\gamma$ 線 密度計, 濃度切換器, 記録計, 沈降容器, 線源移動装置

\footnotetext{
* 昭和 46 年 12 月 25 日受理 昭和 43 年 4 月, 昭和 44 年 4 月, 日本釯業会春季研究 講演発表会に発表

1. 正会員 北海道工業開発試験所

2. 北海道工業開発試験所

3. 正会員 工博 北海道工業開発試験所企画課長
}

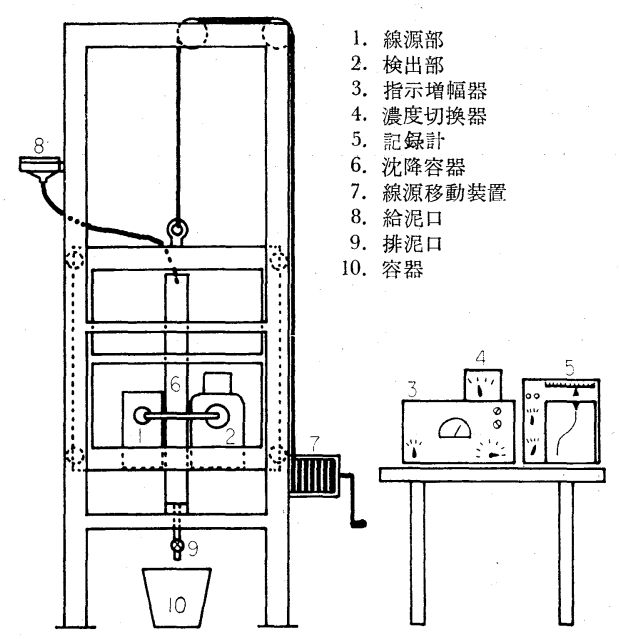

第1 図 $r$ 線沈降濃度測定装置略図

などからなる。

線源部はセシウム $137,250 \mathrm{mC}$ と補償用電離箱が, ま た検出部には電離箱と振動容量形の前置増幅器が内蔵さ れている。増幅器は出力電圧の変化幅が $1,000 \mathrm{mV}$, 時 定数 100 秒と 30 秒に設定されて㧍り, 濃度切換器は増幅 器から出た指示值をその濃度に応じて三段階に切りかえ るものである。沈降容器は内径 $10 \mathrm{~cm}$, 長さ $110 \mathrm{~cm}$ の透 明ポリアクリル樹脂管で, この沈降容器の中心線とビー ムの中心が一致するように支持されている。また線源部 と検出部を支持している支持枠全体をウインチで上下に $1 \mathrm{~m}$ 移動できるようにした。

\section{3. $\gamma$ 線密度計の精度と検量線}

$\gamma$ 線で懸濁液密度を測定する場合に，その精度におよ ぼす扮もな要因として, 質量吸収係数, 線源の崩壊にと もなら統計的変動そして基準密度による較正などがあげ ら、れる質量吸収係数は密度測定の場合, 被測定物質の 種類や状態によつて変わらないことが必要である。また 質量吸收係数は $\gamma$ 線エネルギーの大きさと透過物質の原 子番号によつて変化する。実験使用した密度計のエネ ルギーは $0.662 \mathrm{MeV}$ で元素による吸収保数の変化は第 1 表のようになる ${ }^{14)}$ 。また混合物や化合物についての吸収 係数はそれを構成する元素の吸収係数とその元素の占め 
第 1 表 石炭・岩石などを構成する成分の質量吸収係数

\begin{tabular}{|c|c|c|c|c|c|c|}
\hline 元 & 素 & 分 析 & 成 分 & 供 & 試 & 料 \\
\hline $\begin{array}{l}\mathrm{H} \\
\mathrm{Na} \\
\mathrm{Al} \\
\mathrm{Si} \\
\mathrm{C} \\
\mathrm{N} \\
\mathrm{O} \\
\mathrm{Ca} \\
\mathrm{Fe} \\
\mathrm{K} \\
\mathrm{Mg} \\
\mathrm{S}\end{array}$ & $\begin{array}{l}0.152 \\
0.073 \\
0.074 \\
0.077 \\
0.077 \\
0.077 \\
0.077 \\
0.078 \\
0.073 \\
0.075 \\
0.076 \\
0.078\end{array}$ & $\begin{array}{l}\mathrm{SiO}_{2} \\
\mathrm{Al}_{2} \mathrm{O}_{3} \\
\mathrm{Fe}_{2} \mathrm{O}_{3} \\
\mathrm{CaO} \\
\mathrm{MgO} \\
\mathrm{Na}{ }_{2} \mathrm{O} \\
\mathrm{K}_{2} \mathrm{O} \\
\mathrm{H}_{2} \mathrm{O} \\
\mathrm{CaCO}_{3} \\
\mathrm{H}_{2} \mathrm{SO}_{4}\end{array}$ & $\begin{array}{l}0.077 \\
0.077 \\
0.075 \\
0.077 \\
0.076 \\
0.074 \\
0.075 \\
0.085 \\
0.077 \\
0.079\end{array}$ & 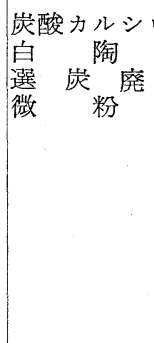 & $\begin{array}{c}\text { ウ } \\
\pm \\
\pm \\
\text { 水 } \\
\text { 崖 }\end{array}$ & $\begin{array}{l}0.077 \\
0.076 \\
0.077 \\
0.077\end{array}$ \\
\hline
\end{tabular}

第 2 表 供試料の化学分析結果 (\%)

\begin{tabular}{l|c|c|c}
\hline 成 分 & 選炭廃水 & 微 粉 岸 & 白 陶 土 \\
\hline $\mathrm{SiO}_{2}$ & 63.38 & 3.92 & 77.96 \\
$\mathrm{Al}_{2} \mathrm{O}_{3}$ & 15.09 & 0.82 & 17.63 \\
$\mathrm{Fe}_{2} \mathrm{O}_{3}$ & 6.28 & 0.34 & 0.24 \\
$\mathrm{CaO}$ & 3.60 & 0.50 & 0.08 \\
$\mathrm{MgO}$ & 1.89 & 0.23 & 0.15 \\
$\mathrm{Na}$ & 0.98 & 0.06 & tr. \\
$\mathrm{K}_{2} \mathrm{O}$ & 2.54 & 0.26 & tr. \\
$\mathrm{Ig} . \operatorname{loss}$ & 5.84 & 93.87 & 3.39 \\
合 計 & 99.57 & 100.00 & 99.45 \\
\hline
\end{tabular}

第 3 表 供試料の粒度構成・平均比重 · 平均圧分

\begin{tabular}{|c|c|c|c|c|c|}
\hline & & 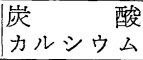 & 白陶土 & 選炭廃水 & 微粉炭 \\
\hline & 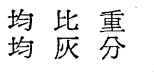 & $\begin{array}{r}2.712 \\
-\end{array}$ & $\begin{array}{r}2.688 \\
-\end{array}$ & $\begin{array}{c}2.485 \\
84.16 \%\end{array}$ & $\begin{array}{l}1.272 \\
6.13 \%\end{array}$ \\
\hline 粒 & $\begin{array}{c}+100 \text { mesh } \\
100 \sim 150 \\
150 \sim 200 \\
200 \sim 250 \\
250 \sim 325\end{array}$ & $\%$ & $\%$ & $\begin{array}{l}0.28 \% \\
0.60 \\
1.23 \\
0.66 \\
4.99\end{array}$ & $\begin{array}{c}7.37 \% \\
9.82 \\
11.75 \\
5.06 \\
16.62\end{array}$ \\
\hline 構 & +325 & 0.64 & 0.24 & 7.76 & 50.62 \\
\hline 成 & $\begin{array}{c}44 \sim 30 \mu \\
30 \sim 20 \\
20 \sim 10 \\
-10\end{array}$ & $\begin{array}{r}55.54 \\
33.26 \\
9.26 \\
1.30\end{array}$ & $\begin{array}{r}6.40 \\
17.30 \\
64.06 \\
12.00\end{array}$ & $\begin{array}{r}12.01 \\
8.51 \\
19.08 \\
52.64\end{array}$ & $\begin{array}{r}26.13 \\
10.18 \\
8.31 \\
4.76\end{array}$ \\
\hline
\end{tabular}

る重量組成比を相乗し, その和で求められる。第 2 表に実 験に供した試料の化学分析結果を示した。沈降性炭酸力 ルシウムは一級試薬で, 白陶士は市販のものを使用した。 また選炭廃水と微粉炭は北炭夕張炭鉣から採取したもの である。微粉炭の灰分は $6.13 \%$ ある。これら試料の質 量吸収係数值は扮扝よそ第 1 表に示した通りである。

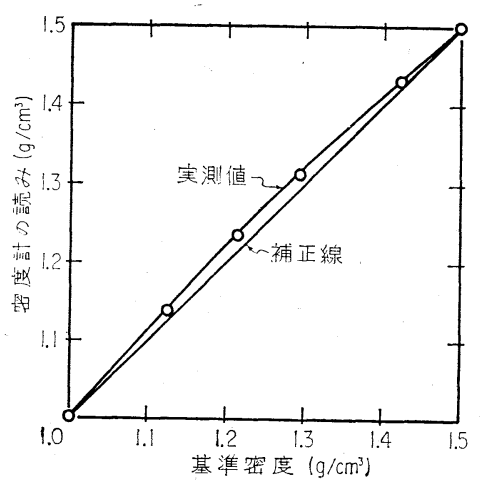

第 2 図

補正曲線

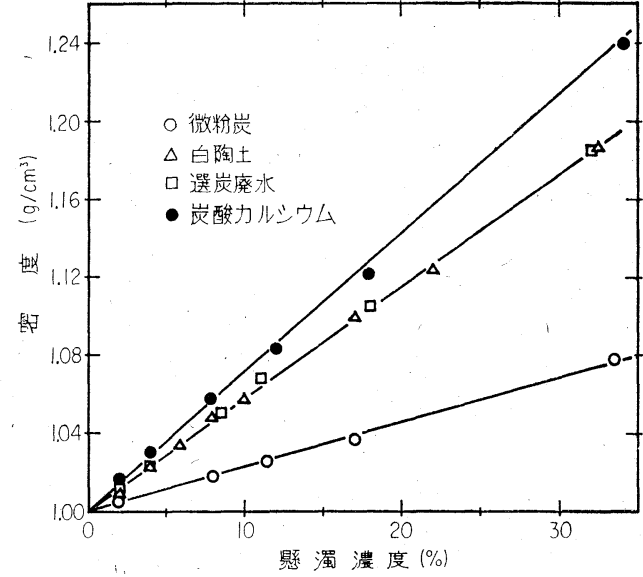

第 3 図 供試料の検量線

この表でわかるように試料の吸収係数值の差は小さく, これによる䛊差は無視できるほどであることがわかる。 な抢微粉炭の分析值は第 2 表の通りであるが, 灼熱減量 のらち $\mathrm{H}_{2} \mathrm{O}$ は $5.60 \%$ て 残りをCとして計算した。

線源の崩壊による統計的誤差は本装置の場合, 時定数 が 100 秒で $\pm 0.002 \mathrm{~g} / \mathrm{cm}^{3} ， 30$ 秒で $\pm 0.005 \mathrm{~g} / \mathrm{cm}^{3}$ 以下で ある。また基準密度による較正は実験で使用した液体が 水で，この密度を最低基準 1.0 とし，最高基準は沈殿層 の密度を考え 1.5 として較正した。この基準液には質量 吸収係数が試料とほとんど変わらない硫酸を用いた。そ してこれと等価吸収する校正板を作り，適時これにより 線源の較正を行なつた。

つぎに物質の密度と $\gamma$ 線指示電圧(密度)值との関係は 指数函数であるため直線上にのらなくなる。この直線性 を得るた为補正する必要がある。そして最高と最低基準 点が較正されているので中間值で最大のずれを生ずる。 密度1: 0 と 1.5 の間で 4 種の密度の硫酸を作り，これを実 測して補正值を求的た。その結果を第 2 図に示す。

以上の結果を考えて最終的精度を求的るめ試料につ いて標準比重計で測定した懸濁液を $\gamma$ 線密度計で測定し 補正して検量線を求为た。その結果を第 3 図に示す。

縦軸の密度は補正して表示した。図から測点のばらつ きが直線から 1 目盛 $\left(0.04 \mathrm{~g} / \mathrm{cm}^{3}\right)$ の $1 / 20$ 程度であり， これは $\pm 0.002 \mathrm{~g} / \mathrm{cm}^{3}$ に相当する。

これらの結果から質量吸収係数，線源の崩壊に伴なう 統計的な誤差は測定記録にすでに含まれている。そして 各試料毎の実測值はばらつきを計算し，その最大誤差は $0.002 \mathrm{~g} / \mathrm{cm}^{3}$ である。

\section{4. 懸濁粒子の沈降挙動}

第 3 表に試料の粒度分布，平均比重および平均灰分を 示す。

まず所定の濃度に調整した矁濁液をよく攪拌し，すみ 


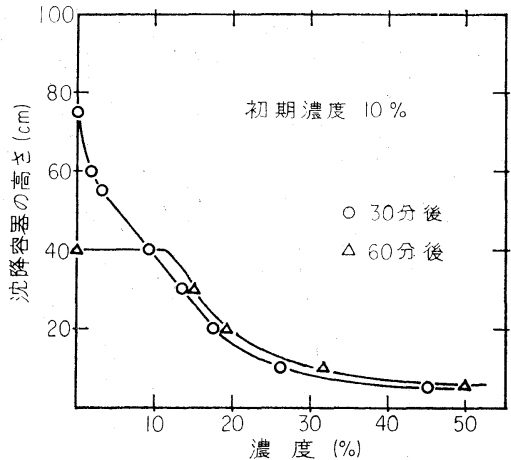

第 4 図＼cjkstart沈降性炭酸カルシウムの垂直濃度変化

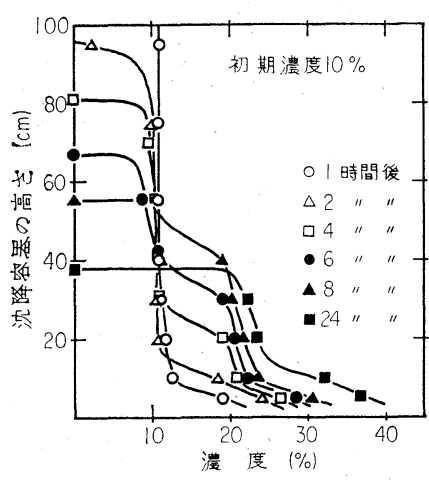

第 5 図 白陶土の垂直濃度変化

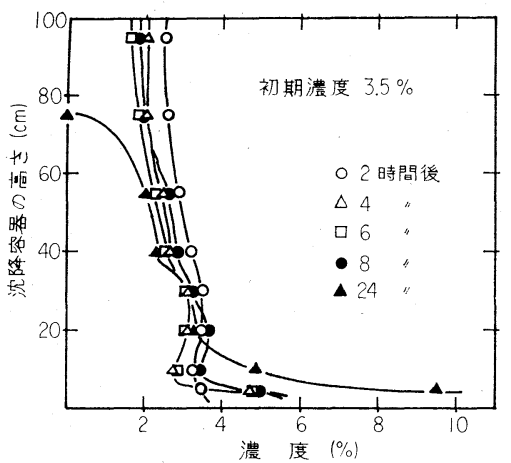

第 6 図 選定廃水の垂直濃度変化
やかに沈降容器内に流入し測定を行なう。測定するもの は沈降容器の下端から $5,10,20,30,40,55,75,95 \mathrm{~cm}$ の位 置に打ける濃度である。測定液温は $21^{\circ} \mathrm{C}, \mathrm{pH}$ 自然 $\mathrm{pH}$ であつた。

第 4 図は沈降性炭酸カルシウムで, 沈降30分, 60分後 の垂直莀度変化を示し，掞なじく第 5 図に白陶土，第 6 図に選炭廃水についての変化を示す。第7 7 図は微粉炭の 場合で，沈降開始後60分までの経時的濃度変化を示す。

これらの結果から炭酸カルシウムでは高さ方向に連続 して濃度が増加し，白陶土では中間的な濃度層が存在す る。また選炭廃水では経時的濃度変化が顕著でなく，高 さ方向に濃度の逆転現象が見られる。微粉炭は経時的に 見て連続した濃度変化をしていることがわかる。

\section{5. 凝集作用における沈降挙動}

つづいて前述の懸濁液に凝集剂を添加し，沈降させた 場合の垂直濃度変化を測定した。

この実験では粒子がフロックとなり，したがつて沈降 が速いため第 1 図で示した装置では測定できない。その 目的にあつた線源と時定数をもつ装置が必要であつた。 この実験は公害資源研究所で行なわれたものである。

装置は第 1 図で述べたものとほぼ同様であるが ${ }^{11)}$ ，線 源はセシウム $137,500 \mathrm{mC}$ であり，沈降容器は塩化ビ二 一ル製で内径 $10 \mathrm{~cm}$ ，有効高さ $103 \mathrm{~cm}$ である。また上下 移動はモータドライブになつている。装置の精度は線源 を止めて測定したとき，抬よび上下走行をさせて測定し たとき，ともに時定数 2 秒で $\pm 0.010 \mathrm{~g} / \mathrm{cm}^{3}$ であつた。

なお実験では密度計の走行速度を $40 \mathrm{~cm} /$ 分として測定 した。

試料は白陶土と選炭廃水の 2 種とし，凝集剤はフロッ クの性状を考えて硫酸ばん土 $5 \%$ 水溶液とセパラン N P

$101 \%$ 水溶液の 2 種とした。

実験は試料を $2.5 ， 5 ， 7.5 \%$ 濃度に調整・攪拌し， さらに凝集剤を加えて 5 分間攪汼した。そしてすみやか に沈降容器内に流入して測定を行なつた。測定は初め 30 分間連続測定し， $1,1.5,2,2.5,3,4,5,6,7,8$,

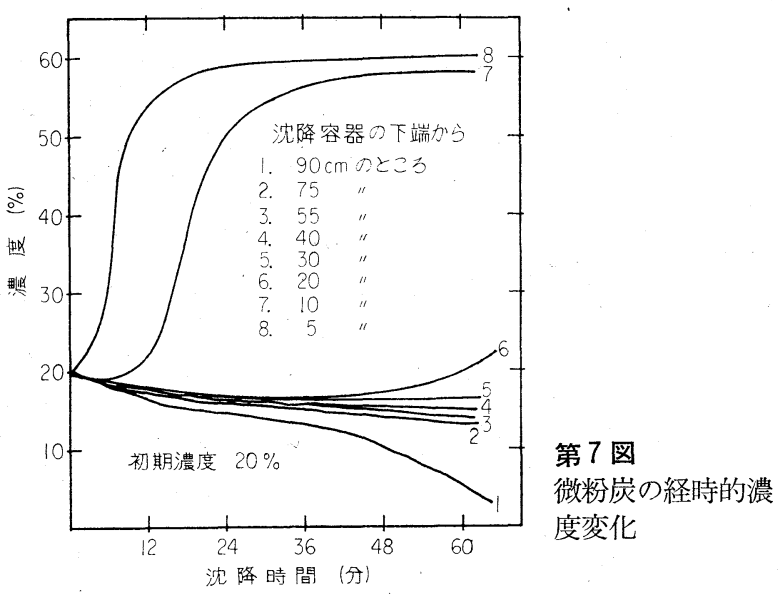

そして24.時間後におのおの10分間ずつ沈降容器の上下を 走查し, 測定した。なお測定液温は $8 \sim 13^{\circ} \mathrm{C}$ で, 自然 $\mathrm{pH}$ であつた。

第 8 図は白陶土 $2.5 \%$ (密度 $1.04 \mathrm{~g} / \mathrm{cm}^{3}$ )の場合の経時 的濃度変化で, 沈降容器の下端から $3,10,20,30,40,50$, $60,70 \mathrm{~cm}$ の位置に打ける変化を示す。経時的に連続した 濃度変化が見られる。第 9 図にこの場合の濃度分布を示 す。沈降時間 0 と圧縮点を結尔面 (不連続面 ${ }^{5}$ ) 以後に ほぼ沈降界面から下底に連続して濃度が高くなつている ことがわかる。

第10図注白陶土 $5 \%$ （密度 $1.08 \mathrm{~g} / \mathrm{cm}^{3}$ ）の濃度分布を 示す。 $1.08 \mathrm{~g} / \mathrm{cm}^{3}$ の濃度層の濃縮が遅く, したがつて界 面の沈降が遅くなつていることがわかる。

第11図は選炭廃水 $2.5 \%$ （密度 $1.04 \mathrm{~g} / \mathrm{cm}^{3}$ ）に硫酸ば ん土を，第12図に同じくセパランN P 10を添加した場合 の濃度分布を示す。第 9 図と同様の傾向を示し, 圧縮点 以後の沈積層内の濃度変化は Kynch などが理論的に述 ベているょうに典型的である。

第13図は選炭廃水 $5 \%$ (密度 $1.07 \mathrm{~g} / \mathrm{cm}^{3}$ ) に硫酸ばん 土50ppmを添加した時の変化を示す。濃度の粗密の逆転 しているところが認められる。第14図にその場合の分布 を示す。また第15図にセパランN P 10を添加した場合の 分布を示す。 


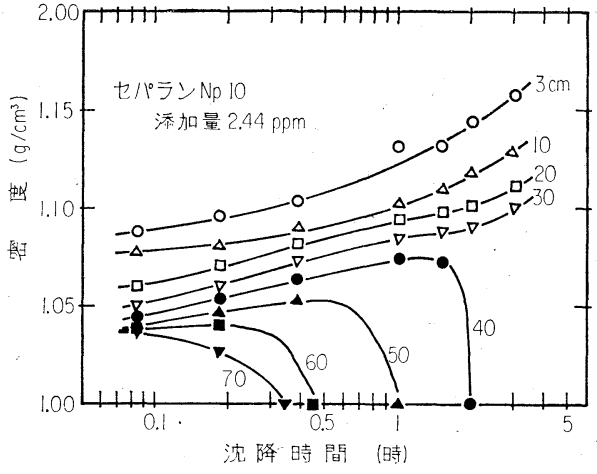

第 8 図 垂直濃度変化 (白陶土 $2.5 \%\left(1.04 \mathrm{~g} / \mathrm{cm}^{3}\right)$ の場合)
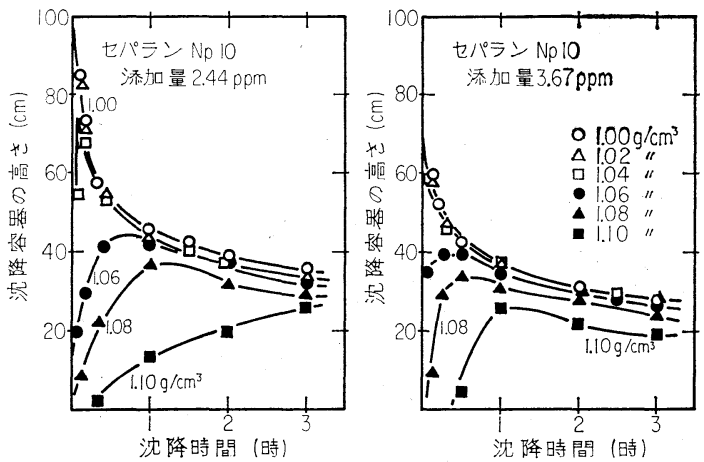

第 9 図 濃度分布曲線 (白陶土 $2.5 \%\left(1.04 \mathrm{~g} / \mathrm{cm}^{3}\right)$ の場合)

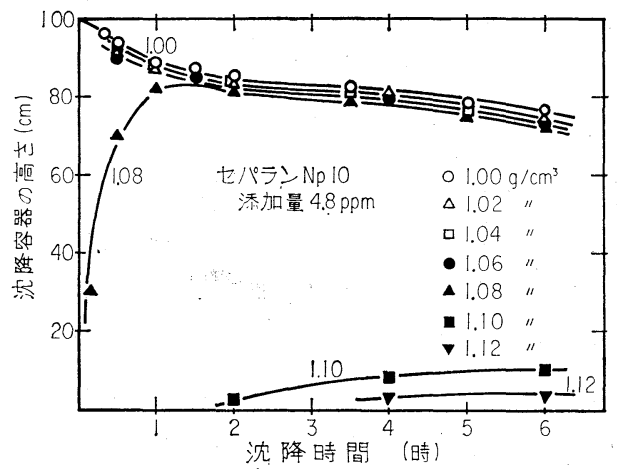

第10図 濃度分布曲線 (白陶土 $5 \%\left(1.08 \mathrm{~g} / \mathrm{cm}^{3}\right)$ の場合)

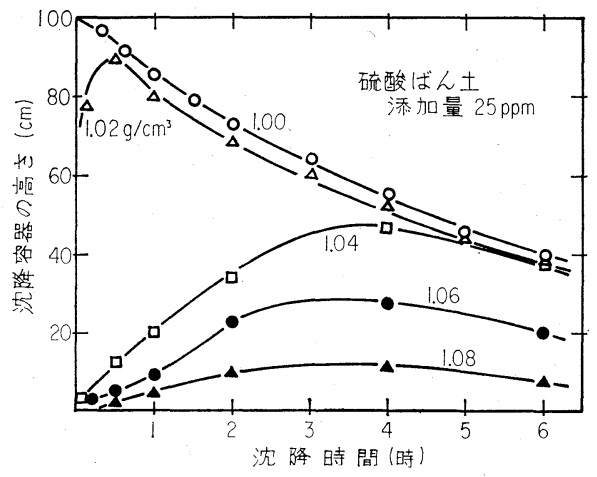

第11図 濃度分布曲線 (選孷廃水 $2.5 \%\left(1.04 \mathrm{~g} / \mathrm{cm}^{3}\right)$ の場合) $608\langle 24\rangle$
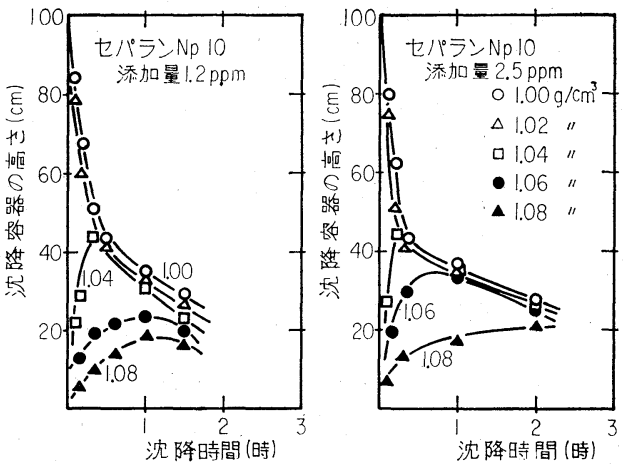

第12図 濃度分布曲線 (選孷廃水 $2.5 \%\left(1.04 \mathrm{~g} / \mathrm{cm}^{3}\right)$ の場合)

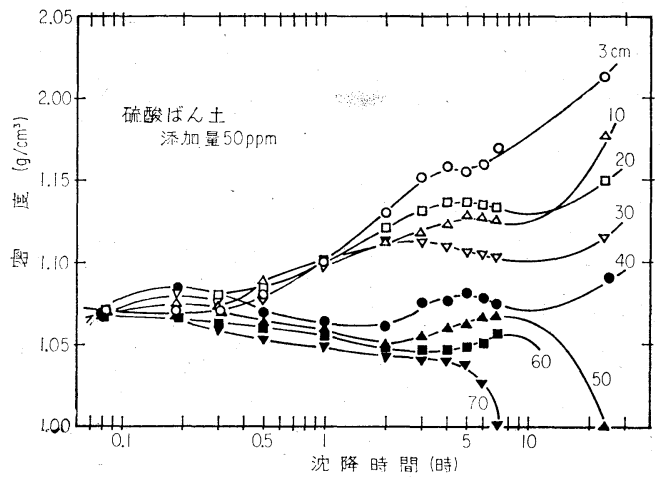

第13図 垂直濃度変化 (選炭廃水 $5 \%\left(1.07 \mathrm{~g} / \mathrm{cm}^{3}\right)$ の場合)

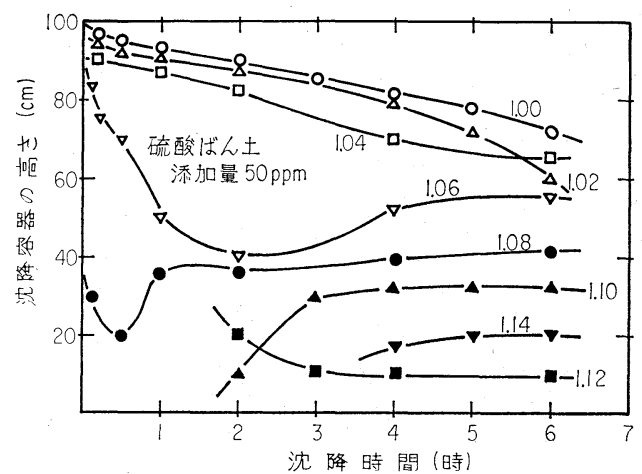

第14図 濃度分布曲線 (選炭廃水 $5 \%\left(1.07 \mathrm{~g} / \mathrm{cm}^{3}\right)$ の場合)

第 16 図は選炭廃水 $7.5 \%$ (密度 $1.11 \mathrm{~g} / \mathrm{cm}^{3}$ ) に硫酸ばん 土を，第17図に同じく硫酸ばん土とセパランN P 10を併 用させた場合の濃度分布を示す。

これらの図の他，前に揭げた図を含为，フロックの性 状によつて沈積層内の挙動が異なることがわかる。すな わち，セパランNP10で生成されるフロックは硫酸ばん 土のそれに比べ硬く，大きいた沈積層内の濃度勾配が 大きい。

\section{6. 考察}

これらの実験結果から沈降の高さ方向における濃度変 化は必ずしも沈降容器の下部に行くほど一様な濃度勾配 をもつて高くなるということではないことがわかる。こ れはおもに固形物の䀣濁状態における粒度構成にあると 


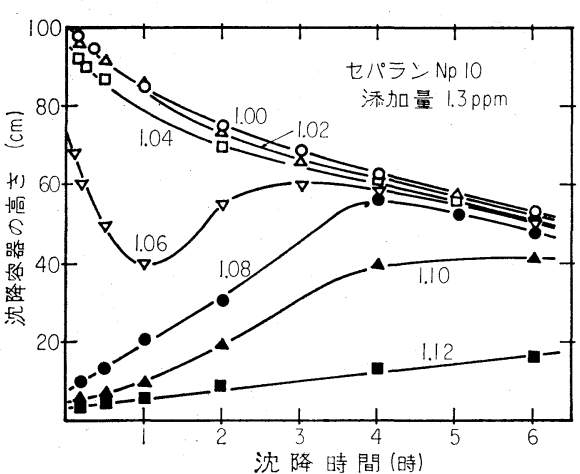

第15図 濃度分布曲線 (選炭廃水 $5 \%\left(1.07 \mathrm{~g} / \mathrm{cm}^{3}\right)$ の場合)

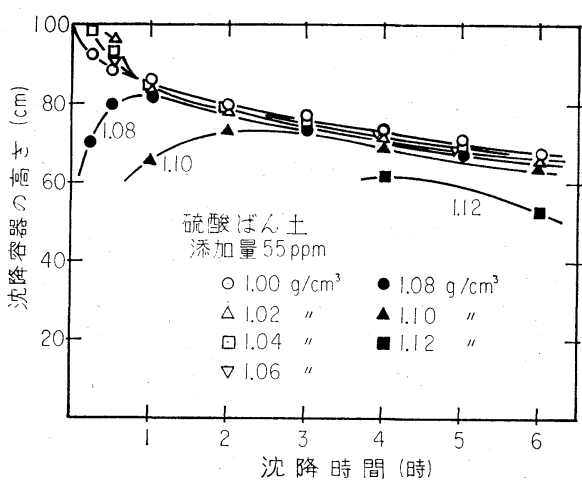

第16図 濃度分布曲線 (選炭廃水7.5\% (1.11g/ $\left./ \mathrm{cm}^{3}\right)$ の場合)

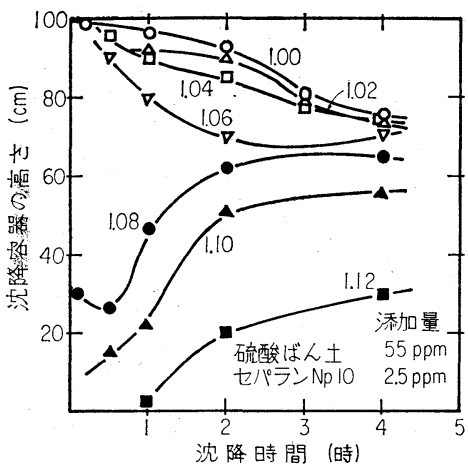

第17図

濃度分布曲線 (選岸廃水 $7.5 \%(1.11 \mathrm{~g} /$ $\left.\mathrm{cm}^{3}\right)$ の場合)

考える。粒度構成が細かい懸濁液は経時的に濃度変化が 小さく, 高さ方向における変化も小さい（選炭廃水な ぞ)。比較的粗い粒度構成の懸濁液は沈積層の高さ方向 の濃度変化が大きい（炭酸カルシウム，微粉炭など）。 また多くが中程度の粒度 $(30 \sim 10 \mu)$ を有する懸濁液の 濃度変化は等速沈降域の低濃度層と圧縮沈降域の高濃度 層との間に中間的な濃度層が形成される（白陶土など）。 これは見掛けのらえで低濃度層は中間濃度層へ濃縮され さらに中間濃度層から高濃度層へ濃縮されているように 考えられる。

一方凝集作用に打的る粒子の挙動はフロックとして取 扱われなければならない。ところがフロックは粒子間の 結合状態によつて見掛壮比重と大きさの分布は異なる。 しかも高濃度懸濁液であるため個々のフロックとしては
存在せず，それらが網状に絡んで巨大なアグリゲートと なつて沈降する。このためフロックの比重や大きさの再 現性は皆無であるといつてよい。実際上フロックの分布 を測定することは不可能である。しかしこの場合の界面 沈降曲線は凝集懸濁液に限らず種々の沈降曲線から比較 してみて，しばしば類似した曲線となる。そしてこの曲 線から懸濁液の凝集をある程度推測できる。第 9 図以後 の濃度分布図で○印で示した密度1.00の曲線が界面沈降 曲線である。これらの曲線を大別すると 2 つ区分でき る。前者は典型的な沈降曲線を描くもので, 等速沈降域 と圧縮沈降域があり，圧縮点が認市られる曲線である。 これは一般に懸濁濃度があまり高くなく, 密度の大きい フロックを作る懸濁液が含まれる。実験では硫酸ばん土 を添加した選炭廃水 $2.5 \%$ とセパラン N P 10を加えた白 陶土 $2.5 \%$ ，選炭廃水 $2.5 \%$ と $5 \%$ の場合である。この場 合の沈降挙動は沈降と高さ方向の濃度との関係でKynch やCoe らの述べた理論に類似している。すなわち等速沈 降区間では沈積層内の垂直濃度変化はほとんどなく，圧 縮点以後の圧縮沈降区間で規則的に連続した濃度勾配を 有する。したがつて沈積濃度は経時的に増大し，界面の 沈降も増加する。後者は一般に沈降速度の遅い場合で, 等速沈降と圧縮沈降との区別が明確でない懸濁液が含ま れる。実験では前に掲げた以外の䀣濁液がこれに該当す る。一般に縣濁固形物濃度が高く, フロックは小さく密 度も小さい。この場合の沈降挙動は濃度の逆転現象など 沈積層内の濃度変化が複雑で不規則である。したがつて この場合の理論的な取扱いは困難であり，今後の問題で ある。

\section{7. 結言}

選炭廃水など均質でない䀣濁液の沈降挙動を理解する には沈積層内の粒子の挙動を知る必要がある。しかしこ れを従来の方法で明らかにすることは測定器などの問題 で実測は困難であつた。そこで筆者らはこの種の測定に $\gamma$ 線密度計の利用を考えた。これによれば高濃度でも不 透明でもよく，また沈降系を乱さず連続的に測定できる などの利点がある。

すなわちセシウム 137 の線源をもつ $\gamma$ 線密度計を装備 した沈降濃度測定装置を試作し，これを使つて測定精度 を求め, さらに種々の沈降挙動を測定した濃度変化から 検討した。

実験で使用した試料についての測定精度は $\pm 0.002 \mathrm{~g} /$ $\mathrm{cm}^{3}$ 以下で，かなりの希薄懸濁液でも測定でき，選炭廃 水などのような広範囲の濃度測定に使用できる。しかし 実測值はあらかじめ基準密度で較正した值に補正してお く必要がある。また真密度で測定されるため, 測定物質 によつて濃度が異なるので各物質ごとに検量線を求めて 打く必要がある。 
この装置を用いて沈降試験を行ない，沈降時間による 沈降方向の濃度変化を測定した。この結果, 沈降容器内 の濃度変化は複雑で，必ずし沈降方向における濃度勾 配は一様に高くなるのではない。

これはおもに固形物の䀣濁状態における比重と粒度構 成によると考えられる。凝集剤を添加すればそのことは 顕著である。

界面の沈降曲線を比較的自由沈降に近い沈降孝する場 合と，干渉沈降が強く沈降する場合とに区別される。前 者は沈降の典型的な場合で理論に類似した挙動を示す。 後者は一般に沈降が遅く，不規則である。したがつてこ の場合の沈降挙動は複雑であり, 理論的な取扱いは困難 である。今後さらに個々の粒子の挙動から検討されなけ ればならない。

謝 辞本報告で述べられた実験の一部は工業技術
院公害資源研究所で行なわれたものである。御指導と御 便宣を賜つた同所もと選炭部第 2 課長手嶋精一氏をはじ 課員の方々に深謝する。

\section{参考文 献}

1) G. J. Kynch: Trans. Faraday Soc. 48161 (1952)

2) E. J. Robetss: Min. Eng-Min. Trans 161 (1949)

3) H. S. Coe, G. H. Clevenger: Trans. AIME 55356 (1916)

4) 吉野善弥 : 化学工学 第28巻第 4 号, 51 (1964)

5) 今泉常正・厷岡耕三：選炭 Vol 10, No. 46107 (1960)

6）井出哲夫・永松定祐 - 角田省吾 : 工業用水，第67号，66，昭和39年 4 月

7）岩佐正夫: 用水之廃水, Vol. 7, No. 9638 (1965)

8) 乙竹 直: 化学工学, 第31巻第 6 号, 605 (1967)

9) K. J. Scott: Trans. Inst. Min. Met. Vol. C77 No. 73985 (1968)

10）三輪博秀・水越 慎：オートメーション，第10巻第11号，13 (1965)

11）山形吉男 - 田中忠次 - 茂呂端生・鈴木繁幸・瀬川 進 - 手島精一：選炭, 第 16 巻第 82 号, 62 , 昭和 41 年

12）関口逸馬・山口義明・植田芳信：日本釷業会春季大会講演要旨 集， Vol 84, No. 959297 (1968)

13）関口逸馬・山口義明・植田芳信 : 日本鉣業会春季大会講演要旨集，昭和 44 年 4 月, 208 頁

14）木村健二郎：放射線データブック，地人書館出版，151

\title{
Studies on Colliery Waste Water Treatment
}

\section{On the behavior of settling particles-}

\author{
by Itsuma SEKIGUCHI, Yoshinobu UEDA and Yoshiaki YAMAGUCHI
}

While the Kynch's the ory serves as a usefull means to elucidate the behavior of settling particles, its applicability is limited by the anomalous behavior of practical suspensions such as in colliery waste water, while the same may be said in regard to the application of the Coe-Clevenger formula.

These formulae were derived with the factors limited to the settling curve of mud line with no consideration to the measured concentration gradient in sedimentation zone.

By conventional methods, however, it was very difficult to measure the concentration gradient, hence, the authors attempted to solve this problem by use of $\gamma$-ray density meter.

Using this method, measurements could be made continuously without disturbing the settling system.

This report describes the accuracy of density measurement and the results of the change of vertical density distribution against time under several conditions using a few samples such as colliery waste water etc.

Namely, accurate measurements within the value of $\pm 0.002 \mathrm{~g} / \mathrm{cm}^{3}$ were obtained and the density of suspensions over wide range were determined. The density destribution in a vertical direction in a settling tube was not always continuously changed. The concentration gradient in the presence of added flocculants was discussed. 